\title{
Communication
}

[Comunicação]

\section{Meningoencephalitis in a horse associated with equine herpesvirus 1}

\author{
[Meningoencefalite em um cavalo associado com herpesvírus eqüino 1] \\ E.A. Costa ${ }^{1}$, G.B.L. Lima ${ }^{1}$, R.T. Castro ${ }^{1}$, R. Furtini ${ }^{2}$, R.V.Portilho ${ }^{3}$, M. Resende ${ }^{1^{*}}$ \\ ${ }^{1}$ Instituto de Ciências Biológicas - UFMG \\ Caixa Postal 486 \\ 31279-901 - Belo Horizonte, MG \\ ${ }^{2}$ Instituto Mineiro de Agropecuária - Belo Horizonte, MG \\ ${ }^{3}$ Médico veterinário autônomo
}

Equine herpesvirus 1 (EHV-1) and equine herpesvirus 4 (EHV-4), members of the Alphaherpesvirus subfamily, are highly prevalent equine pathogens that cause severe economic losses in equine breeding establishments (Mumford and Edington, 1980; Galosi et al., 2001). EHV-1 is associated with respiratory problems, abortion, neonatal death, and neurological damage that can lead to paralysis. EHV-4 (equine rhinopneumonitis) is mostly associated with respiratory disease (Carvalho et al., 2000a,b; Mori et al., 2003), but can also cause neurological disorders in some cases. EHV-4 is much less frequently reported than EHV-1 (Van Maanen, 2002). Remarkably, these two herpesviruses are ubiquitous, and infection is enzootic in most horse populations. In Brazil, the first infections related to EHV-1 were identified following reports of abortions in the states of São Paulo, Minas Gerais, and Rio Grande do Sul (Nilsson and Correa, 1966; Carvalho et al., 1991; Carvalho et al., 2000a,b; Cunha et al., 2002; Diel et al., 2006). Since then, serological studies have attempted to estimate the prevalence and incidence of EHV-1 infection in herds with reproductive problems in these states. High rates of antibody presence have been recorded, with positive values ranging from 27.2 to $84.7 \%$. The conclusion is that EHV-1 is present in Brazil and might have a higher risk of incidence in the offspring of horses that have been reported as positive (Carvalho et al., 1991; Cunha et al.,

Recebido em 1 de agosto de 2008

Aceito em 11 de novembro de 2008

*Autor para correspondência (corresponding author)

E-mail: 1cv@icb.ufmg.br
2002; Diel et al., 2006). Outbreaks of the neurological disease caused by EHV-1 infection have been detected in several countries such as the USA (Allen, 2006), the Netherlands (Goehring et al., 2005), and Australia (Studdert et al., 2003). Marked increases have been noted in recent years (Allen, 2006). Meanwhile, the first report of encephalomyelitis associated with EHV-1 infection in a horse that showed neurological symptoms occurred in the state of São Paulo very recently, in 2007 (Mori et al., 2007).

The following report is a case study that describes ataxia and paresis in a 12-year-old Brasileiro de Hipismo breed stallion.

One morning, an individually-housed stallion became lethargic and refused to eat. Upon initial examination, its heart rate was 38 beats/min and respiratory rate was $28 \mathrm{breaths} / \mathrm{min}$. Its mucous membranes were normochromic and the capillary refill time was $2 \mathrm{sec}$. Gastric content taken with a nasogastric tube showed no evidence of abnormality. The stallion received $8 \mathrm{~L}$ of intravenous (IV) lactated Ringer's solution with $10 \mathrm{ml}(25 \mathrm{mg} / \mathrm{ml})$ of ranitidine ${ }^{1}$ and $200 \mathrm{ml}$ $(0.5 \mathrm{~g} / \mathrm{ml})$ of sorbitol ${ }^{2}$.

In response to the treatment, the condition of the stallion improved. Appetite and intestinal flux rapidly recovered. The urination and defecation soon returned to normal ranges.

\footnotetext{
${ }^{1}$ Antak ${ }^{\circledR}$ - GlaxoSmithKline - Rio de Janeiro, Brazil.

${ }^{2}$ Sedacol - Laboratórios Calbos Ltda - Curitiba, Brazil.
} 
Three hours later, the effectiveness of the IV fluid therapy abruptly deteriorated. The animal was found ataxic with a pronounced paresis that seriously affected the forelimbs. The stallion leaned forward severely and ended up falling onto its neck. Soon, it stood up, but it looked apprehensive and was very sensitive to touch in the neck, lumbar region and hind limbs. Through a catheter, 41 of yellowish gastric content were removed.

The animal was medicated with 61 of lactated Ringer's solution with $15 \mathrm{~mL}(50 \mathrm{mg} / \mathrm{ml})$ of flunixin-meglumine ${ }^{3}, \quad 2 \mathrm{ml} \quad(5 \mathrm{mg} / \mathrm{ml}), \quad 2 \mathrm{ml}$ $(5 \mathrm{mg} / \mathrm{ml})$ of bromopride ${ }^{4}$, and $2 \mathrm{~g}$ of omeprazol ${ }^{5}$. Following treatment, the head tilted forwards and the animal fell down and quickly stood up. At that point, it also exhibited whole-body tremors. The animal was subsequently transported to a veterinary teaching hospital and upon initial examination, it was found unresponsive and depressed. Upon further evaluation, mild congestion from ocular and oral mucous was noted. No dehydration was detected, the capillary refill time was $2 \mathrm{sec}$, the heart rate was 41 beats $/ \mathrm{min}$, and the respiratory rate was $11 \mathrm{breaths} / \mathrm{min}$. Gastrointestinal sounds were weak and the animal dribbled urine. Upon transrenal examination, the bladder was found grossly distended and this was relieved by catheterization (141 of urine). Response to bladder evacuation was rapid and intestinal movements subsequently normalized.

Examination revealed an intestinal cavity sound, but one intestinal loop on the right side was over the cecum. A blood sample was submitted to a complete blood cell count (CBC) and serum biochemical analysis. A urine sample was also submitted to urinalysis. The $\mathrm{CBC}$ count showed a mild normocytic and normochromic anemia. The chemistry panel indicated a marked increase of creatine phosphokinase (4896U/1), lactic acid dehydrogenase $(856 \mathrm{U} / \mathrm{l})$, and calcium $(9.8 \mathrm{mg} / \mathrm{dl})$. Chloride $(85 \mathrm{mEq} / \mathrm{l})$ was found to be low.

Lack of coordination remained a problem and the animal was given 71 of IV glycophysiological solution that included $20 \%$ calcium

${ }^{3}$ Banamine ${ }^{\circledR}$ - Schering-Plough Veterinária - São Paulo, Brazil.

${ }^{4}$ Digestina - União Química e Farmaceutica. Nacional S.A. São Paulo, Brazil.

${ }^{5}$ Equiprazol 300g - Vetnil - São Paulo, Brazil. borogluconate $^{6}$. The animal developed stiffness and ataxia. It was unable to remain standing for long periods and was unsteady, falling forward onto its neck on several occasions. Nystagmus was observed in both eyes together with respiratory distress. Excessive bronchial fluid consistent with pulmonary edema was noted.

As the condition of the stallion continued to deteriorate, the animal received $200 \mathrm{mg}(2 \mathrm{mg} / \mathrm{ml})$ of dexamethasone ${ }^{7}, 51$ of lactated Ringer's solution, $200 \mathrm{~g}$ of dimethyl sulfoxide ${ }^{8}$, followed by IV potassium benzyl penicillin ${ }^{9}$ $(10,000,000 \mathrm{IU})$, and sodium benzyl penicillin ${ }^{10}$ $(20,000,000 \mathrm{IU})$. Following this treatment, the respiratory distress was alleviated but the animal remained hyperesthetic and still had muscle tremors, shifting from one leg to another; afterwards, the muscle tremors became more pronounced. Ataxia remained a problem, causing repeated episodes of bumping into the wall and multiple falls. Because of this - and further complicating its condition - the stallion developed wounds on the head and on some areas of the body. Due to extreme excitation and proprioceptive loss, resulting in near-continuous falling behavior, the animal was tranquilized with $2 \mathrm{~g}$ of IV sodium phenobarbital ${ }^{11}$. This sedated the stallion for less than an hour.

The condition of the animal continued to deteriorate; its movements became violent and unpredictable. This sudden onset of seizures and ataxia was followed by respiratory distress and by marked cyanotic mucous. There was a severe loss of proprioceptive feedback; after a particularly violent seizure, the animal fell and struck its head on the stable floor. The animal experienced respiratory paralysis. In a final attempt to restore the vital signs, it received $200 \mathrm{mg}$ of dexamethasone and $10 \mathrm{ml}$ of adrenalin $^{12}$, followed by respiratory and cardiac massage. Those attempts were unsuccessful and

${ }^{6}$ Calfomag ${ }^{\circledR}$ - Laboratório Leivas Leite - Pelotas, Brazil.

${ }^{7}$ Azium ${ }^{\circledR}$ - Schering-Plough S.A. - São Paulo, Brazil.

${ }^{8}$ DMSO - Promega Corporation - Madison, USA.

${ }^{9}$ Pentacilin Large animals - Fort Dodge Animal Health Ltda São Paulo, Brazil.

${ }^{10}$ Sodium Benzyl Penicillin ${ }^{\circledR}$ - Veterquimica - Santiago, Chile.

${ }^{11}$ Tiopental - Cristália Produtos Químicos Farmacêuticos Itapira, Brazil.

${ }^{12}$ Adrenalina Braun ${ }^{\circledR}$ - Laboratórios B. Braun S.A. - São Gonçalo, Brazil. 


\section{Costa et al.}

the condition of the stallion continued to deteriorate over the next 12 hours.

The animal died with a clinical diagnosis of encephalomyelitis. A postmortem exam was immediately conducted. The brain and other tissues were sent for virological and histological examination.

The animal had gross lung edema and congestion. The left cranial lobe was consolidated. A few liters of brownish fluid containing fibrin strands were present in the thoracic cavity. The tracheal mucus had gross, scattered, and blotchy hemorrhages. Hemorrhagic lesions or petechias were observed on many tissues and organs, such as renal cortex, jejunal mucous and serous fluid, bladder, peritoneum, and on the glandular portion of the stomach. The esophageal mucous contained multiple grey-whitish foci, $2 \mathrm{~mm}$ diameter. Besides, some bruising points on the head and scattered hemorrhagic abrasions in the body, no other external abnormalities were found. Scattered hemorrhages were seen on the surface of the leptomeninges. The brain had no marked macroscopic or microscopic findings.

Samples pooled from central nervous system (CNS) tissues were tested by PCR for the possible presence of EHV-1 and EHV-4 DNA. The PCR assays used specific glycoprotein B (gB) gene primers for EHV-1 and EHV-4. They were performed in accordance with the protocols described by Ballagi-Pordány et al. (1990) and Varrasso et al. (2001), respectively. Only EHV-1 DNA was detected. The precise sequence of the amplicon was confirmed by automated DNA sequencing ${ }^{13}$. The nucleotide sequence of the 779 strain obtained in this study has been deposited in the NCBI Nucleotide Sequences Databases with the accession number DQ864706. Nucleotide and aminoacid alignments in the 294 bp of the gB region of the 779 strain showed 100\% similarity with V592 (AY464052), Ab4 (AY665713), RacL11 (X95374), and HVS 25A (D00401). A definitive neurological diagnosis of EHV-1 can only be supported by EHV-1 isolation, identification of viral particles, inclusions, antigens, or nucleic acids from the cerebrospinal fluid (CSF) or brain tissue (Carvalho et al., 2000a,b).

In this case, besides EHV-4, the horse was confirmed negative for rabies by means of indirect immunofluorescence testing and mice inoculation. Both of these viruses are considered differential diagnoses of neurological diseases in horses.

The prognosis for EHV-1 neural disease is related to the length of decumbency. It has been shown that recumbent horses have a good chance of developing complications. Recovery may be long, and some animals may sustain mild neurological deficits. Bladder paralysis is also commonly associated with the condition (Wilson, 1997). There is currently no available vaccine that protects against the neurological form of EHV-1 (Allen, 2006).

Keywords: equine herpesvirus 1, neurological signs, clinical case, diagnosis

\section{RESUMO}

Um garanhão da raça Brasileiro de Hipismo, de 12 anos de idade, apresentou um quadro neurológico complexo, que se assemelhava, em vários aspectos, aos sinais neurológicos causados pelo herpesvírus eqüino 1 (EHV-1), variando desde uma suave ataxia à completa paralisia dos posteriores. $O$ animal morreu com menos de 12 horas após o início dos sinais nervosos. O diagnóstico de EHV-1 foi feito pela detecção do DNA viral no sistema nervoso central por meio da reação em cadeia da polimerase (PCR) $e$ posterior sequenciamento.

Palavras-chave: herpesvírus eqüino 1, sinais neurológicos, caso clínico, diagnóstico

\footnotetext{
${ }^{13}$ MegaBaceTM 1000 - Amersham Biosciences - England.
} 


\section{ACKNOWLEDGEMENTS}

We thank the veterinary practitioners who have participated in this study. This study was supported by CNPq grant 305045/2003-2 and FAPEMIG.

\section{REFERENCES}

ALLEN, G.P. Antemortem detection of horses latently infected with neuropathogenic strains of equine herpesvirus-1. Am. J. Vet. Res., v.67, p.1401-1405, 2006.

BALLAGI-PORDANY, A.; KLINGEBORN, B.; FLENSBURG, J. et al. Equine herpesvirus type 1: Detection of viral DNA sequences in aborted fetuses with the polymerase chain reaction. Vet. Microbiol., v.22, p.373-381, 1990.

CARVALHO, R.; PASSOS, L.M.; OLIVEIRA, A.M. et al. Detection of equine herpesvirus 1 DNA in a single embryo and in horse semen by polymerase chain reaction. Arq. Bras. Med. Vet. Zootec.,v.52, p.302-306, 2000a.

CARVALHO, R.; PASSOS, L.M.; GOUVEA, A.M.G. et al. Use of an ELISA system for detection of equine herpesvirus 1 (EHV-1) antibodies in non-symptomatic pregnant mares and neonatal foals. Arq. Bras. Med. Vet. Zootec., v.52, p.200-207, 2000b.

CARVALHO, F.S.R.; COELHO, H.E.; BEDAQUE, M. Aborto eqüino por herpesvirus eqüino 1. Rev. Centro Cienc. Biom. UFU., v.7, p.45-47, 1991.

CUNHA, E.M.S.; FERRARI, C.I.L.; LARA, M.C.C.S.H. et al. Presença de anticorpos contra o herpesvirus eqüino 1 (HVE-1) em eqüinos no noroeste do estado de São Paulo. Arq. Inst.Biol., v.69, p.1-5, 2002.

DIEL, D.G.; DE ALMEIDA, S.R.; WEIBLEN, R. et al. Prevalência de anticorpos contra os vírus da influenza, da arterite viral e herpesvírus em eqüinos do estado do Rio Grande do Sul, Brasil. Cienc. Rural, v.36, p.1467-1673, 2006.
GALOSI, C.M.; VILA ROSA, M.V.; OLIVA, G.A. et al. A polymerase chain reaction for detection of equine herpesvirus-1 in routine diagnostic submissions of tissues from aborted fetuses. J. Vet. Med. B, v.48, p.341-346, 2001.

GOEHRING, L.S.; VAN MAANEN, C.; VAN OLDRUITENBORGH-OOSTERBAAN, M.M.S Neurological syndromes among horses in the Netherlands. A 5 years retrospective survey (1999-2004). Vet. Q., v. 27, p.11-20, 2005.

MORI, E.; LARA, M.C.C.S.H.; CUNHA, E.M.S. et al. Isolamento de herpesvirus eqüino tipo 1 (HVE-1) a partir do líquor de um cavalo com doença neurológica: primeiro relato no Brasil. Biológico, v.69, p.113-198, 2007.

MORI, E.; MORI C.M.C.; DELLA LIBERA, A.M.M.P. et al. Evaluation of alveolar macrophage function after experimental infection with equine herpesvirus-1 in horses. Arq. Bras. Med. Vet. Zootec., v.55, p. 271-278, 2003.

MUMFORD, J. A.; EDINGTON, N. EHV-1 and equine paresis. Vet. Rec., v.106, p.277, 1980.

NILSSON, M.R.; CORREA, W.M. Isolamento do vírus do aborto eqüino no estado de São Paulo. Arq. Inst.Biol., v.33, p.23-25, 1966.

STUDDERT, M.J.; HARTLEY, C.A.; DYNON, J.R. et al. Outbreak of equine herpesvirus type 1 myeloencephalitis: new insights from virus identification by PCR and the application of an EHV-1-specific antibody detection ELISA. Vet. Rec., v.153, p.417-423, 2003.

VAN MAANEN, C. Equine herpesvirus 1 and 4 infections: an update. Vet. Q., v.4, p.58-78, 2002.

VARRASSO, A.; DYNON, K.; FICORILLI, N. et al. Identification of equine herpesviruses 1 and 4 by polymerase chain reaction. Aust. Vet. J., v.79, p.563-569, 2001.

WILSON, W.D. Equine herpesvirus 1 myeloencephalopathy. Vet. Clin. N. Am.: Equine Pract., v.13, p.53-72, 1997. 